\title{
ks. Marcin Godawa, Obraz tajemnicy Wcielenia i Narodzenia Pańskiego w retorycznych medytacjach wybranych autorów środowiska krakowskiego w pierwszej połowie XVII wieku, Kraków 2013, 418 s.
}

Obraz tajemnicy Wcielenia i Narodzenia Pańskiegow retorycznych medytacjach wybranych autorów środowiska krakowskiego w I połowie XVII wieku to niezwykle interesująca książka ks. dra Marcina Godawy, adiunkta Katedry Teologii Duchowości i pracownika Instytutu Duchowości na Wydziale Teologicznym Uniwersytetu Papieskiego Jana Pawła II w Krakowie. Autor w swych badaniach okazuje się godnym kontynuatorem takich znawców historii polskiej duchowości jak Karol Górski, Jerzy Misiurek czy Jarosław Popławski. W swej książce podjął się analizy dzieł autorów pierwszej połowy XVII wieku. Szczególnie cenne jest to, że sięgnął nie po szeroko komentowane i dobrze znane postaci tego okresu, takie jak Piotr Skarga, Mikołaj Łęczycki, Kacper Drużbicki czy Hieronim Powodowski, ale po autorów związanych ze środowiskiem krakowskim, spośród których jak dotądjedynie Mikołaj z Mościsk doczekał się szerszego opracowania. Ks. Marcin Godawa skoncentrował się na twórczości Fabiana Birkowskiego (1566-1636), Mikołaja z Mościsk (1559-1632), Adama Opatowiusza (1574-1647), Szymona Starowolskiego (15881656) i Jacka Liberiusza (1599-1673). Już samo przedstawienie powyższych mało znanych nawet w środowisku teologów duchowości autorów i ich twórczości zasługuje na uznanie i przyczynia się do rozwoju nauki. Autor w swej książce omawia dzieła polskojęzyczne, głównie kazania i medytacje, gdyżjego celem jest badanie wydanego za kościelną aprobatą nauczania skierowanego głównie ku religijnemu pożytkowi ludzi świeckich.

Z uwagi na kryterium funkcjonalne ks. Godawa potraktował zarówno rozmyślania, jak i kazania jako jednostki reprezentujące modlitwę myślną. Jak sam stwierdził, przedmiotem wyznaczającym profil jego badań jest ob ra z tajemnic wiary, czyli r etoryczno-teologiczna kompozycja elementów doktryny dokonana ze względu na intelektualny moment medytacji. Dlatego w oryginalny sposób ukazał bogactwo semantyczne tajemnicy wcielenia i narodzenia Pańskiego w podwójnej, zarówno teologicznej, jak i retorycznej perspektywie. Nie są to jednak w książce ks. Godawy niezależne i niejako ustawione obok siebie perspektywy, gdyż analiza formy i treści, perspektywa retoryczna i teologiczna wzajemnie się przenikają i ubogacają, prowadząc do nowych, oryginalnych wniosków. Widać to wyraźnie w układzie pracy. W perspektywie teologiczno-retorycznej ks. Godawa ukazuje bogactwo semantyczne tajemnicy inkarnacji i narodzenia. Posługując się schematem teologii odgórnej, prowadzi czytelnika w trzech rozdziałach od tajemnicy Trójcy Świętej do Jezusa, wcielonego Syna Bożego i następnie do Jego Matki. W takim ujęciu merytoryczna treść refleksji teologicznej łączy się z analizą retoryczną, ukazując kształtowanie się boskiego komunikatu, jego aktualizację w Chrystusie i przyjęcie go przez reprezentującą ludzkość Maryję. Taki układ książki jest oryginalny i stanowi kwintesencję obranej perspektywy retoryczno-teologicznej. Obie perspektywy sprawiają, że odpowiednio przygotowany czytelnik może docenić zarówno głębię teologicznej refleksji,jak i specjalistyczny aparat pojęciowy retoryki, którymi cechuje się twórczość ks. Godawy.

Książka stanowi solidne, źródłowe, oryginalne i ciekawe studium osadzone w szerokim kontekście historycznym i kulturowym, ukazujące pozytywno-scholastyczną meto- 
dologię omawianych autorów, ich myśl teo- ków Kościoła, teologów duchowości, znawlogiczną i niezwykle bogatą strategię reto- ców retoryki i homiletyki. ryczną. Monografia ks. dra Marcina Godawy stanowi cenne źródło refleksji dla history-

ks. Wojciech Zyzak 